\title{
NETWORKS OF DIRECTORS ON RUSSIAN BOARDS: THE HIDDEN PART OF THE CORPORATE GOVERNANCE ICEBERG
}

\author{
M.A. ZAVERTIAEVA \\ International Laboratory of Intangible-driven Economy, \\ National Research University Higher School of Economics, Russia ${ }^{a}$ \\ F. J. LÓPEZ-ITURRIAGA \\ School of Business and Economics, Universidad de Valladolid, Spain ${ }^{\mathrm{b}}$ \\ International Laboratory of Intangible-driven Economy, \\ National Research University Higher School of Economics, Russia ${ }^{a}$
}

\begin{abstract}
In this paper we apply social network analysis to study the boards of directors of 107 large listed Russian firms between 2009 and 2014. Traditional corporate governance metrics, such as demographic characteristics, experience, or multiple directorships, confirm that the boards of Russian firms show greater independence and are more well-qualified than before. We also find a decrease in the centrality of directors, which corroborates the diminishing concentration of power of some directors. The most connected firms have a specific profile since they are larger, have lower market valuations, and stronger ties with government (both due to higher proportions of government owned shares and a greater number of directors who are former politicians). Our findings also demonstrate that the boards of financial institutions are less connected, whereas political and independent directors are more centralized.
\end{abstract}

Keywords: boards of directors, corporate governance, Russia, social networks.

JEL: G34, C45.

\footnotetext{
This study comprises research findings from the project No. 18-18-00270 supported by the Russian Science Foundation.

Postal Addresses: a 37, bul. Gagarina, International Laboratory of Intangible-driven Economy, National Research University Higher School of Economics, Perm, 614060, Russia; ${ }^{\text {b }} 6$, Av. Valle de Esgueva, School of Business and Economics, Universidad de Valladolid, Valladolid, 47011, Spain.
}

(c) M.A. Zavertiaeva, F.J. López-Iturriaga, 2020

https://doi.org/10.21638/spbu18.2020.102 


\section{INTRODUCTION}

The Russian Corporate Governance (CG) system was created after the transition from a planned economy to a market one in conditions of crisis [Goriaev, Zabotkin, 2006]. Since then, CG indicators, such as the proportion of independent directors, the number of board meetings and board size, have significantly grown [Enikolopov, Stepanov, 2013; Lazareva et al., 2008].

However, traditional CG indicators, suggested by the agency theory, only describe the tip of the iceberg for Russian companies. It is common for firms in emerging economies to face resource scarcity as formal institutions fail and markets are underdeveloped. In such a context, the resource dependence view, which posits that knowledge, expertise and relationships of directors can provide a firm with critical resources, offers a sound theoretical foundation [Pfeffer, Salancik, 2003]. According to this view, director connections with other companies are particularly important, given a firms' need for more links to the external environment in emerging markets.

The importance of director connections in emerging countries has given rise to the empirical analysis of networks in Brazil [Mendes-da-Silva, 2011], India [De, 2012], South Africa [Durbach, Parker, 2009], Chile [Silva, Majluf, Paredes, 2006], Thailand [Sitthipongpanich, Polsiri, 2015], and Taiwan [Chan et al., 2017]. As for Russia, S. Michailova and V. Worm argue that personal connections have existed for centuries and remain extremely important in modern companies since they are "products of specific cultural heritages" [Michailova, Worm, 2003]. However, despite wide-ranging discussion in the theoretical literature, networks of Russian directors have yet to be empirically explored. Do Russian director connections differ from those in other developing markets? How do Russian firms address market conditions using director connections? What kinds of directors are felt to be the most important resources?
Our paper represents the first step towards quantitatively analysing Russian boards' connections.

In our analysis we apply the Social Networks Analysis (SNA) technique. This provides detailed information about a director's place in the network and the extent of the benefits that can be derived [Singh, Delios, 2017]. The chosen metrics determine number of connections that directors have (degree centrality), extent to which they act as mediators between other firms within a network (betweenness centrality), closeness to other firms in the network (closeness centrality), as well as importance of the neighbouring directors (eigenvector centrality). We also analyse whether certain types of directors are more important in the network than others. Particular attention is paid to the directors that affiliated with financial institutions, as well as directors in government- and oligarch-owned companies that are considered to be valuable in the Russian business environment.

We examine a sample of 107 large listed Russian companies between 2009 and 2014. Since economic turbulence may lead to major changes in the network [Withers, Kim, Howard, 2018], we choose the period between two crises: the world economic crisis of 2008 and the Russian financial crisis that commenced in late 2014. The unit of observation is an individual director, while each firm employs up to 22 directors. Thus, the total sample includes 6,729 directoryear observations.

The main contribution of the paper is the analysis of director networks among Russian firms using the resource dependence view and applying the social network analysis technique. Although this descriptive approach could be seen as restrictive, the relevance of research derives not only from the fact that CG is a promising field for the application of social networks, but also because the Russian environment is characterized by the importance of relations. The social network approach might prove more useful in this environment than

PЖM 18 (1): 29-50 (2020) 
in most developed capital markets on which previous inquiries have focused. Similar to the descriptive papers [Mendes-da-Silva, 2011; Durbach, Parker, 2009] that analyse director networks in emerging countries, we aim to develop a point of reference for future works on the Russian market as well as other emerging ones.

The remainder of the paper is as follows. Section 1 provides the fundamental explanations of the importance of networks of directors and the theoretical foundations underlying the impact of connections on corporate governance. Section 2 introduces the methodology of network metrics. Section 3 describes the sample and some characteristics of the firms studied. Section 4 reports and discusses the results of the analysis using descriptive statistics and means comparisons. The final section concludes and provides a number of future directions for research.

\section{THEORETICAL BACKGROUND}

Among corporate governance mechanisms, the Board of Directors (BoD hereinafter) emerges as the apex of the system and is the focus of international public authority efforts to enhance CG [Iwasaki, 2014; Steckler, Clark, 2019]. The BoD plays a twofold role in large firms: monitoring and supervising managers on behalf of shareholders and acting as a valuable source of knowledge, finance and other intangible resources for the firm [Adams, Hermalin, Weisbach, 2010; Lai, Chen, Song, 2019]. Dependent on which role is more prominent, two main theories have been advocated as foundations of BoD studies: the agency theory and the resource dependence view [Chen, Hsu, Chang, 2016; Schiehll, Martins, 2016; Zona, Boyd, Takacs Haynes, 2019]. The agency theory underlines the conflicts of interests between managers and shareholders and stresses how directors monitor managers in order to protect shareholder interests. In this context, director independence emerges as a key issue. However it should be noted that independent directors usually serve on several boards, which may lead to a reduction in efficiency.

Studies on developed markets usually describe a trade-off between the costs and benefits of hiring busy directors through the lens of agency theory. Fich and Shivdasani show how directors serving on multiple boards are overcommitted, which may result in poor firm performance [Fich, Shivdasani, 2006]. Devos, Prevost and Puthenpurackal conclude that US firms with lower industry-adjusted performance are more likely to have interlocking directors [Devos, Prevost, Puthenpurackal, 2009]. In the German market, firms with more embedded boards have been found to perform worse [Andres, van den Bongard, Lehmann, 2013; Böhler, Rapp, Wolff, 2010]. Evidence consistent with this result has been found for Japanese firms [Kawai, Ko, 2012]. In contrast, the literature reporting the positive effects of multiple directorships has usually studied future rather than current firm performance [Horton, Millo, Serafeim, 2012; Larcker, So, Wang, 2013].

The resource dependence view focuses on which resources directors bring to the company, among which connections play a key role [Madhani, 2017]. From this point of view, attention should be paid to which characteristics of directors serve to amplify the firm's network. Prior research [Zona, Gomez-Mejia, Withers, 2018; BlancoAlcántara, Díez-Esteban, Romero-Merino, 2018 ] state that while agency theory is more applicable when resources are abundant, the resource dependence view has more explanatory power for resource constraints, as is the case of emerging markets like Russia. In such a scenario, connected directors can bring resources that help to overcome market frictions, provide self-generated institutional support, leverage bureaucratic connections, and influence the media [Cárdenas, 2015; Purkayastha, Manolova, Edelman, 2012; Yigit, Behram, 2013]. Empirical evidence on the effect of director networks in emerging countries supports the idea that such networks are far more beneficial when 
compared to developed countries. Director connections have a positive effect on performance in Chinese [Qiao, Fung, Ju, 2013], Chilean [Silva, Majluf, Paredes, 2006], Thai [Sitthipongpanich, Polsiri, 2015], Colombian [Pombo, Gutiérrez, 2011], and Indian firms [Singh, Delios, 2017]. However, the findings of [Kim, 2005] and [Santos, da Silveira, Barros, 2012] suggest there is a breakpoint in the "busyness" of directors after which it may prove detrimental to corporate performance.

\section{METHODOLOGY}

The literature usually employs three main measures to study BoD: the number of directorships, the interlocks, and social networks. The first measure only accounts for the number of boards on which a particular director serves and the term "busyness" has been coined to describe the situation in which a director is included on several boards usually more than three [Andres, van den Bongard, Lehmann, 2013; Core, Holthausen, Larcker, 1999]. Director interlock happens when an insider of one firm serves as an outside director of another or vice versa. Some researchers analyse more specific cases, such as reciprocal interlocks of CEOs [Fich, White, 2005], ownership-director interlocks [Bohman, 2012; Comet, Pizarro, 2011], or corporate linear triples, whereby two corporations share directors with the board of the third firm [Hayden, Garner, Hoffman, 2013].

The third set of metrics borrows the social network analysis technique and usually uses four main indicators (degree centrality, betweenness centrality, closeness centrality, and eigenvector centrality) to assess involvement in a network and the relative importance of a given node ${ }^{1}$ [Chuluun, Prevost, Puthenpurackal, 2014; Freeman, 1978; Schonlau, Singh, 2009]. This approach, recently applied in corporate governance anal-

\footnotetext{
${ }^{1}$ In our paper, each node represents one director.
}

ysis, outperforms other techniques since it uniquely captures several dimensions of connections, such as the quality of the connections and the position of each director's connections within the network [Barnea, Guedj, 2007].

Director interactions with one another via formal (that is, board meetings) and informal contacts create a network. According to the literature, formal contacts have the advantage of not being affected by personal biases. M. S. Granovetter posits that formal contacts influence performance even more that informal ones do [Granovetter, 1973]. Also, formal contacts are seen as a good proxy for their informal counterparts [Andres, van den Bongard, Lehmann, 2013]. Further, directors who are well-connected in terms of formally determined ties, can also be well-connected in terms of informal contacts outside the boardroom. That is why the paper focuses on formal director connections: two directors are connected if they are included in the same board. Companies become connected when they share members of company boards. Fig. 1 shows how a director network appears. Fig. 1.a represents the links between three companies (1-3) and seven board directors (A-G). Fig. 1.b reports formal connections between directors $A-G$ formed by their serving on the same board.

Degree centrality is one of the most intuitive measures and is defined as the number of links a given director has, i.e., with how many different directors he or she is in direct contact with through sitting on the same board. Directors with more connections tend to have more power and to be more visible. However, degree does not take into account indirect relationships and a director's importance in knowledge diffusion. Fig. 1 shows how each of the directors $\mathrm{A}, \mathrm{F}$ and $\mathrm{G}$, has only two connections, so their degree of centrality equals 2 . Director $\mathrm{E}$ has the highest degree, equal to 5 .

Betweenness centrality quantifies the number of times a given director is the shortest path between two other directors. The underlying idea concerns how many pairs of direc-

PЖM 18 (1): 29-50 (2020) 


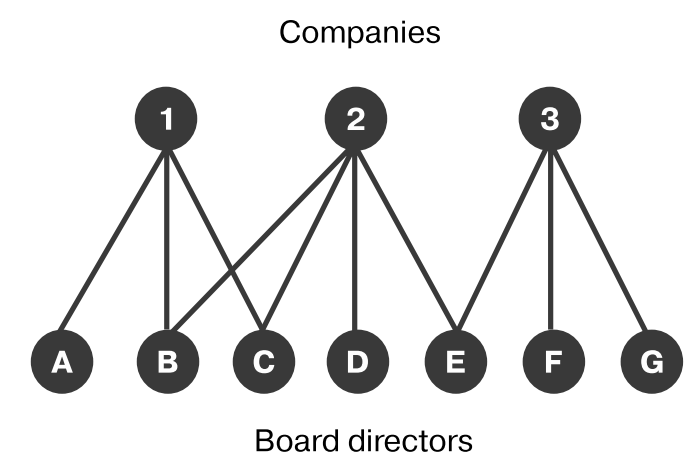

(a) Connection between boards and directors

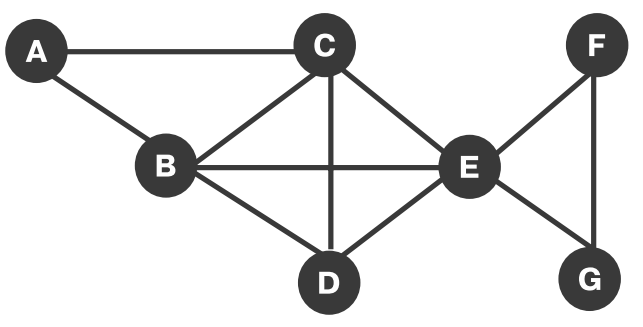

(b) Network of board directors

Fig. 1. A scheme of board directors' networks

B a sed o n: [Mendes-Da-Silva, 2011].

tors the analysed director has to go through to reach another in the smallest number of steps. Thus, it can be viewed as a measure of the control a director can have on the communication between two other directors. Betweenness measures a director's ability to bridge subnetworks.

Closeness centrality is the average length of the shortest path between a director and all the other directors on the boards of Russian firms. The more central a director is, the closer he or she is to all other directors. Consequently, closeness can be regarded as a measure of how long it will take to spread information or influence from one director to all the other directors sequentially. Closeness and betweenness characterise a position of a director in the network that is important to identify the extent of benefits that a firm can derive [Singh, Delios, 2017].

Eigenvector centrality is a measure of the influence of a director in the network of Russian directors and is founded on the idea that not all directors are equally important or influential. Eigenvector centrality assigns relative scores to all the directors in the network based on the concept that connections to high-scoring directors contribute more to scores than equal connections to low-scoring directors. The higher a director's eigenvector score, the more he or she is connected to other directors who themselves have high scores. In other words, it estimates the popularity of a director's direct connections.

The definitions of the variables, terms related to network analysis, and formulas to calculate centrality metrics are provided in Appendix 1.

\section{SAMPLE}

The database used in this research includes large listed Russian companies whose shares are actively traded. The sample consists of 633 firm-year observations from 107 firms, which are included at least once in the Moscow Exchange Broad Market Index (MICEX BMI) between 2009 and 2014. This index consists of the top 100 shares, selected by liquidity, capitalization and free-float. Since the unit of observation is a director, and each firm employs up to 22 directors, the sample consists of 6729 director-year observations.

A number of different sources was used to collect the data. Financial information was gathered using the Ruslana database provided by Bureau van Dijk ${ }^{2}$. Information on board

\footnotetext{
${ }^{2}$ https://ruslana.bvdep.com/
} 
Table 1

Descriptive statistics of the sample

\begin{tabular}{l|c|c|c|c|c}
\hline \multicolumn{1}{c|}{ Variable } & Mean & Median & Std. Dev. & Min & Max \\
\hline Leverage & 1.44 & 0.70 & 2.90 & 0.01 & 36.39 \\
\hline Age & 20.09 & 14.00 & 22.17 & 1.00 & 126.00 \\
\hline Size & 8.01 & 7.70 & 1.42 & 4.76 & 12.62 \\
\hline ROIC & 0.10 & 0.07 & 0.13 & -0.29 & 0.82 \\
\hline Price-to-book value & 1.57 & 1.01 & 1.66 & 0.06 & 10.99 \\
\hline Share of Government ownership (\%) & 4.39 & 0.10 & 15.81 & 0.00 & 100.00 \\
\hline Share of large shareholder (\%) & 8.10 & 0.00 & 21.46 & 0.00 & 86.63 \\
\hline
\end{tabular}

Note: leverage is calculated as the ratio of debt to equity book value. Age is the number of years since the creation of the firm. Size is measured as a logarithm of book value. Return on invested capital (ROIC) is calculated as the ratio of net operating profit after taxes to the invested capital of the previous period. Price-to-book value is defined as the equity market value to book value ratio. Share of government ownership represents a percentage of state owners of a company shares (both direct and indirect). $n=380$.

compositions was collected from the companies' websites and annual reports. Personal details on board members were hand-collected from annual reports and websites containing information on leading Russian managers.

Table 1 outlines the descriptive statistics of the firms included in the sample. According to the data, $4.39 \%$ of shares are held by the State, similar to the $3.32 \%$ reported in [Muravyev, Berezinets, Ilina, 2014]. This figure is driven by the state holding a large fraction of shares in some companies since the median state stake is close to zero. The mean shares held by large shareholders (so-called oligarchs) is $8.01 \%$, although the median equals 0 . Both state and large shareholder ownership display major inequality within the sample.

The median firm in the sample has less debt than equity, and an equity market price almost equal to its book value. The low level of leverage and market-to-book value found in Russian firms as compared to European or US companies can be explained by reference to the underdevelopment of Russian financial markets and their idiosyncratic corporate finance. Debt is usually considered to be the most risky and expensive source of funds. Thus, Russian firms rely primarily on retained earnings and do not incur debt until they have depleted their internal funds.
Almost $70 \%$ of the sample are companies from the energy, chemical and manufacturing industries (Fig. 2). The sample industry structure resembles the Russian economy, i.e. one that is known for the prevalence of the oil and gas sector and manufacturing. Most of the companies are located in Moscow and Saint-Petersburg (57\%). The other 43\% of sample companies are located in regional cities (Fig. 3).

\section{EMPIRICAL RESULTS}

\subsection{Basic statistics}

Table 2 provides demographic information on directors and their educational attainments.

A director in the network is, on average, 48 years old and male. A. Muravyev reports an average age of 45.4 [Muravyev, 2017]. Our sample of Russian directors is slightly younger than their European or American counterparts. The averages are: 59 years old for French directors, 61 for German, and 62.6 for American directors [SpencerStuart, 2018]. In recent years, the average age of Russian directors has, however, tended to increase. From the point of view of the resource dependence theory, this tendency has 


\section{Directors' background and demographic statistics}

\begin{tabular}{l|c|c|c|c}
\hline \multicolumn{1}{c|}{ Variable } & Mean & $\begin{array}{c}\text { Std. } \\
\text { Dev. }\end{array}$ & Min & Max \\
\hline Age & 48.37 & 10.99 & 22.00 & 85.00 \\
\hline $\begin{array}{l}\text { Higher education } \\
\text { (at least one } \\
\text { degree) }\end{array}$ & 0.30 & - & - & - \\
\hline $\begin{array}{l}\text { Number } \\
\text { of degrees }\end{array}$ & 0.41 & 0.68 & 0.00 & 2.00 \\
\hline MBA degree & 0.10 & - & - & - \\
\hline $\begin{array}{l}\text { Proportion } \\
\text { of women }\end{array}$ & 0.09 & - & - & - \\
\hline
\end{tabular}

Note: $n=6512$.

a positive implication for firms since older (and supposedly more experienced) directors bring more valuable resources to the firm in the form of outside connections. Although the issue lies beyond the scope of this research, the proportion of female directors $(9 \%)$ is very low.

Table 3 reports statistics on directors' levels of experience and "busyness".

A high proportion of directors (around $76 \%$ ) have work experience within the industry in which the company operates. Further, almost half of the directors have been a CEO at some point. International experience increases year upon year, while the share of politically connected directors decreases. The data suggest that between $21 \%$ and $28 \%$ of directors have experience working abroad. Although this percentage is lower than in most European countries, it may reflect improved CG in large Russian companies, given that people with international experience may have a broader view and apply knowledge that differs from Russian practices. Once again, Russian directors seem to bring valuable resources (in terms of international experience) to the firm. At the same time, the decrease in the share of government experience means that political connections are becoming less important when it comes to managing large companies. Despite being less

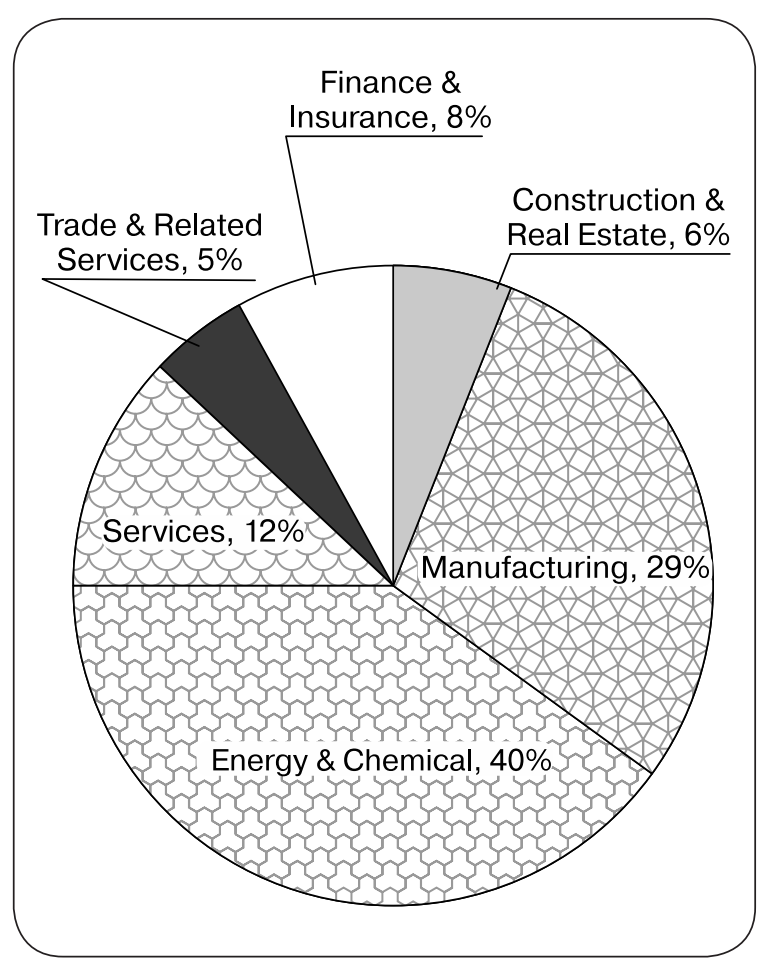

Fig. 2. Industry structure of the sample

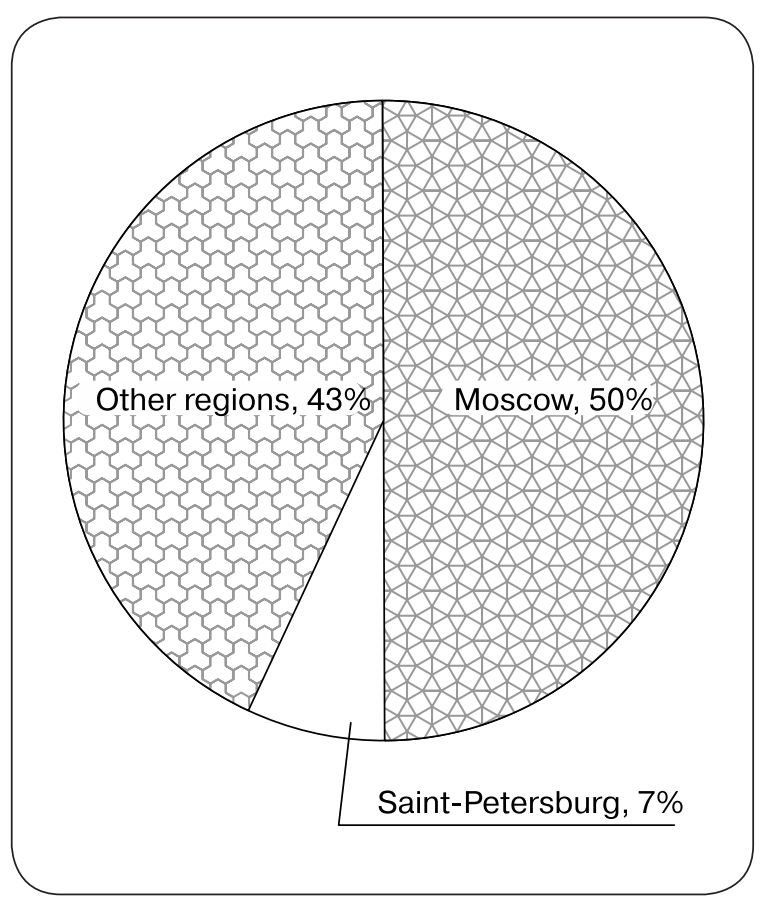

Fig. 3. Location of companies 
Table 3

Directors' experience and occupation by year

\begin{tabular}{c|c|c|c|c|c|c|c}
\hline Year & $\mathbf{n}$ & $\begin{array}{c}\text { International } \\
\text { experience }\end{array}$ & $\begin{array}{c}\text { Industry } \\
\text { experience }\end{array}$ & $\begin{array}{c}\text { CEO } \\
\text { experience }\end{array}$ & $\begin{array}{c}\text { Government } \\
\text { experience }\end{array}$ & Entrants & Directorships \\
\hline 2009 & 1102 & 0.21 & 0.76 & 0.50 & 0.24 & 0.24 & 2.59 \\
\hline 2010 & 1124 & 0.21 & 0.74 & 0.47 & 0.25 & 0.19 & 2.46 \\
\hline 2011 & 1124 & 0.23 & 0.75 & 0.48 & 0.23 & 0.22 & 2.28 \\
\hline 2012 & 1149 & 0.25 & 0.75 & 0.49 & 0.20 & 0.18 & 2.31 \\
\hline 2013 & 1124 & 0.27 & 0.75 & 0.46 & 0.19 & 0.19 & 2.16 \\
\hline 2014 & 1094 & 0.28 & 0.77 & 0.45 & 0.21 & 0.18 & 2.32 \\
\hline
\end{tabular}

N o t e: columns "International experience", "Government experience", "Industry experience" and "CEO experience" are the proportion of directors in the sample who have a corresponding type of work experience. "Entrants" indicates the proportion of directors hired in a particular year. The variable "Directorships" reflects the average number of other boards for all directors.

connected, these directors are likely to be more independent from political pressures and, thus, have a greater possibility for independent oversight of managers. The percentage of newly appointed directors remains quite stable at around $20 \%$. The average number of boards on which directors sit has fallen from 2.59 to 2.32. Given the limited possibility of performing one's duties efficiently when sitting on many boards, the agency approach suggests that the decrease in the number of multiple directorships may result in improved CG.

Table 4 contains some firm-level descriptive statistics of boards, including size of the board, proportion of busy directors, proportion of independent directors, and proportion of interlocked directors.

The average board of a large, listed Russian company contains approximately ten directors, which is consistent with the nine directors reported in [Dolgopyatova, 2003]. Among the largest European countries, the average size varies between eight directors in Poland and 13.9 in France [SpencerStuart, 2018]. In turn, if the size of the board could be viewed as a proxy of boardroom talent, Russian firms are in an intermediate position relative to other European firms.

The independent director is a member of a board who does not have a material or pecuniary relationship with the firm. With the exception of 2014, the share of independent directors has risen each year, which is also a sign of the board's improved ability to supervise managers. The proportion of independent directors ranges between 25\% and $32 \%$, which is slightly lower than the data of [Iwasaki, 2008; 2013; 2014], and is consistent with figures from the survey of [Frye, Iwasaki, 2011]. The closest sample to the one used in the current paper is that of [Prokofieva, Muniandy, 2011], who report an average independence rate of $40 \%$.

Table 4 also provides information on the share of sample firms connected through interlocking directorates. Listed Russian firms are highly connected since the share of interlocked companies varies between $75 \%$ and $80 \%$, although this percentage decreased over time. In terms of network analysis, this means that in the Russian corporate system there are large director networks that can reach most firms.

Taken together, these results reflect that more independent and expert CG practices took place in large Russian companies over the period observed. Both international experience and the proportion of independent directors have increased, whereas the percentage of politically connected directors and excessive multiple directorships has fall- 
Characteristics of the boards of firms in the sample

Table 4

\begin{tabular}{|c|c|c|c|c|c|c|}
\hline Variable & Year & $\mathbf{n}$ & Mean & Std. Dev. & Min & $\operatorname{Max}$ \\
\hline $\mathbf{1}$ & 2 & 3 & 4 & 5 & 6 & 7 \\
\hline \multirow[t]{6}{*}{ Size of the board } & 2009 & 107 & 10.03 & 2.57 & 5.00 & 17.00 \\
\hline & 2010 & 107 & 10.23 & 2.74 & 5.00 & 22.00 \\
\hline & 2011 & 107 & 10.15 & 2.55 & 5.00 & 19.00 \\
\hline & 2012 & 107 & 10.21 & 2.48 & 6.00 & 18.00 \\
\hline & 2013 & 107 & 10.24 & 2.65 & 6.00 & 18.00 \\
\hline & 2014 & 107 & 10.09 & 2.57 & 5.00 & 18.00 \\
\hline \multirow[t]{6}{*}{ Share of busy directors } & 2009 & 107 & 0.43 & 0.36 & 0.00 & 1.00 \\
\hline & 2010 & 107 & 0.41 & 0.35 & 0.00 & 1.00 \\
\hline & 2011 & 107 & 0.41 & 0.34 & 0.00 & 1.00 \\
\hline & 2012 & 107 & 0.40 & 0.33 & 0.00 & 1.00 \\
\hline & 2013 & 107 & 0.38 & 0.34 & 0.00 & 1.00 \\
\hline & 2014 & 107 & 0.42 & 0.34 & 0.00 & 1.00 \\
\hline \multirow[t]{6}{*}{ Share of independent directors } & 2009 & 97 & 0.25 & 0.26 & 0.00 & 1.00 \\
\hline & 2010 & 97 & 0.27 & 0.27 & 0.00 & 1.00 \\
\hline & 2011 & 97 & 0.29 & 0.28 & 0.00 & 1.00 \\
\hline & 2012 & 97 & 0.30 & 0.28 & 0.00 & 1.00 \\
\hline & 2013 & 97 & 0.32 & 0.27 & 0.00 & 1.00 \\
\hline & 2014 & 97 & 0.28 & 0.25 & 0.00 & 1.00 \\
\hline \multirow[t]{6}{*}{ Share of interlocked firms } & 2009 & 107 & 0.80 & 0.40 & 0.00 & 1.00 \\
\hline & 2010 & 107 & 0.80 & 0.40 & 0.00 & 1.00 \\
\hline & 2011 & 107 & 0.75 & 0.44 & 0.00 & 1.00 \\
\hline & 2012 & 107 & 0.75 & 0.44 & 0.00 & 1.00 \\
\hline & 2013 & 107 & 0.75 & 0.44 & 0.00 & 1.00 \\
\hline & 2014 & 107 & 0.76 & 0.43 & 0.00 & 1.00 \\
\hline \multirow{6}{*}{$\begin{array}{l}\text { Share of directors connected with } \\
\text { CEO (the same board) }\end{array}$} & 2009 & 107 & 0.022 & 0.082 & 0.00 & 0.455 \\
\hline & 2010 & 107 & 0.030 & 0.099 & 0.00 & 0.545 \\
\hline & 2011 & 107 & 0.030 & 0.092 & 0.00 & 0.545 \\
\hline & 2012 & 107 & 0.021 & 0.085 & 0.00 & 0.545 \\
\hline & 2013 & 107 & 0.010 & 0.054 & 0.00 & 0.364 \\
\hline & 2014 & 107 & 0.020 & 0.089 & 0.00 & 0.636 \\
\hline \multirow{6}{*}{$\begin{array}{l}\text { Share of directors connected with } \\
\text { CEO (the same academic institution) }\end{array}$} & 2009 & 107 & 0.12 & 0.12 & 0.00 & 0.60 \\
\hline & 2010 & 107 & 0.13 & 0.13 & 0.00 & 0.60 \\
\hline & 2011 & 107 & 0.13 & 0.13 & 0.00 & 0.60 \\
\hline & 2012 & 107 & 0.13 & 0.12 & 0.00 & 0.50 \\
\hline & 2013 & 107 & 0.13 & 0.12 & 0.00 & 0.50 \\
\hline & 2014 & 107 & 0.13 & 0.12 & 0.00 & 0.56 \\
\hline
\end{tabular}


en. The size of the boards and the proportion of busy directors are consistent with large European companies. Nevertheless, this data only provides part of the picture - the next section analyses another perspective of CG and networks, and thereby provides a broader understanding of Russian CG.

\subsection{Dynamics of network measures}

In order to calculate network metrics, we used the following two steps:

1) The data collected regarding boards was used to identify all existing pairs of directors. We completed the table in Microsoft Access $^{\circledR}$ using a separate $n \times n$ network matrix for each year. We assigned 1 to a cell $a_{i j}$ if director $i$ and director $j$ are included on the same board, and 0 otherwise. The matrix is thus symmetric. As a result, we had 98456 pairs.

2) We calculated the chosen network metrics using NodeXL software. It is a free, opensource template for Microsoft Excel ${ }^{\circledR}$ that allows for the analysis of social networks using the matrix in Microsoft Access ${ }^{\circledR}$. Although the results from the calculations were not normalized by all possible connections in the network, the number of directors in the network hardly changed between the periods analysed. It was thus possible to use non-normalized values.

Table 5 reports the degree, betweenness, closeness, and eigenvector centrality of the sample directors in dynamics. The definitions of the variables are provided in Appendix 1.

The most consistent results are the decreasing trends of degree and eigenvector centrality. Degree centrality indicates the number of each director's direct relationships. The other metric, eigenvector centrality, describes the relative importance of a director's network, taking into account his or her neighbour networks. This means that, within the network of Russian directors, each person was connected to less important directors in 2014 when compared to 2009 , such that the relative importance of each director decreased. This evolution may be affected by the size of the boards. Nevertheless, since the average board size, according to Table 4, remains more or less the same throughout the period studied, the decrease in both degree and eigenvector centrality could be attributed to the fewer connections and lower importance of connected directors.

It is worth noting that the relationship between closeness and the other metrics of centrality is negative and significant (Appendix 2). Network metrics are normally positively correlated [Li et al., 2015; Valente et al., 2008]. The negative correlation between closeness and the other metrics of centrality might be due to the evolution of the Russian BoD network: the size of the networks has not changed significantly, but the centrality of directors has decreased. Thus, the average distance of each director from another has increased. Another possible explanation is that there may be one or several clusters of directors located far from the rest of the network, which would be consistent with the idea of a more decentralized network.

\subsection{Characteristics of the most connected firms}

In the next stage of our descriptive analysis, we studied whether the most connected firms differ from the rest of the sample. First, we calculate the mean centrality metrics for each company. Then, we define the most connected firms as those in the first quartile of each metric. Next, we report some firm-level characteristics (such as size, valuation, ownership structure) of both groups of firms. Finally, we implement t-tests to check whether there are significant differences between the means of the most connected firms and the rest of the sample. Given the correlation between degree and betweenness, we examined both metrics simultaneously. However, we analysed degree and betweenness together because of their high correlation. The results for all of the comparisons are presented in Table 6. 
Table 5

Centrality metrics

\begin{tabular}{c|c|c|c|c|c}
\hline Year & $\mathbf{n}$ & Degree & Betweenness & Closeness & Eigenvector \\
\hline 2009 & 1102 & 15.592 & 1.840 .924 & 0.03 & 0.0022 \\
\hline 2010 & 1124 & 15.149 & 2.066 .205 & 0.028 & 0.0017 \\
\hline 2011 & 1124 & 14.071 & 2.086 .567 & 0.031 & 0.0017 \\
\hline 2012 & 1149 & 13.870 & 2.353 .077 & 0.030 & 0.0015 \\
\hline 2013 & 1124 & 13.536 & 1.920 .505 & 0.032 & 0.0011 \\
\hline 2014 & 1093 & 12.927 & 1.521 .457 & 0.039 & 0.0015 \\
\hline Total & $\mathbf{6 7 1 6}$ & $\mathbf{1 4 . 1 9 1}$ & $\mathbf{1 . 9 6 8 . 7 5 3}$ & $\mathbf{0 . 0 3 2}$ & $\mathbf{0 . 0 0 1 6}$ \\
\hline
\end{tabular}

Test of mean comparisons of the most connected firms

Table 6

\begin{tabular}{|c|c|c|c|c|c|c|}
\hline \multirow{2}{*}{ Variable } & \multicolumn{3}{|c|}{ Most connected firms } & \multicolumn{3}{|c|}{ Rest of the firms } \\
\hline & $\mathbf{n}$ & Mean & Std. Dev. & $\mathbf{n}$ & Mean & Std. Dev. \\
\hline \multicolumn{7}{|c|}{ Panel A: Definition of the most connected firms according to degree and betweenness } \\
\hline Size & 118 & 8.42 & 0.95 & 331 & $7.99^{* * *}$ & 1.48 \\
\hline Price-to-book value & 107 & 0.96 & 0.76 & 286 & $1.36^{* * *}$ & 1.17 \\
\hline $\begin{array}{l}\text { Share of government } \\
\text { owners }\end{array}$ & 154 & 22.25 & 35.35 & 458 & $6.17^{* * *}$ & 17.30 \\
\hline International experience & 159 & 0.13 & 0.12 & 458 & $0.25^{* * *}$ & 0.23 \\
\hline Government experience & 159 & 0.28 & 0.13 & 458 & $0.20 * \%$ & 0.16 \\
\hline
\end{tabular}

Panel B: Definition of the most connected firms according to closeness

\begin{tabular}{l|c|c|c|c|c|c}
\hline Size & 97 & 7.33 & 1.38 & 352 & $8.25^{* * *}$ & 1.37 \\
\hline $\begin{array}{l}\text { Price-to-book value } \\
\text { Share of government } \\
\text { owners }\end{array}$ & 91 & 1.73 & 1.52 & 302 & $1.19^{* * *}$ & 0.97 \\
\hline $\begin{array}{l}\text { International experience } \\
\text { Government experience }\end{array}$ & 131 & 0.18 & 0.21 & 502 & $0.25^{* * *}$ & 0.22 \\
\hline
\end{tabular}

Panel C: Definition of the most connected firms according to eigenvector

\begin{tabular}{l|c|c|c|c|c|c}
\hline Size & 104 & 8.02 & 1.06 & 345 & 8.07 & 1.50 \\
\hline $\begin{array}{l}\text { Price-to-book value } \\
\begin{array}{l}\text { Share of government } \\
\text { owners }\end{array}\end{array}$ & 159 & 11.75 & 27.45 & 453 & $8.03^{* * *}$ & 20.50 \\
\hline $\begin{array}{l}\text { International experience } \\
\text { Government experience }\end{array}$ & 165 & 0.11 & 0.10 & 468 & $0.27^{* * *}$ & 0.23 \\
\hline
\end{tabular}

Note: $*, * *, * * *$ indicate significance at the 10,5 and $1 \%$ level, respectively. 
Test of mean comparisons of the most isolated firms

\begin{tabular}{c|c|c|c|c|c|c}
\hline \multirow{2}{*}{ Variable } & \multicolumn{3}{|c|}{ Isolated firms } & \multicolumn{3}{c}{ Rest of the firms } \\
\cline { 2 - 7 } & $\mathbf{n}$ & Mean & Std. Dev. & n & Mean & Std. Dev. \\
\hline 1 & 2 & 3 & 4 & 5 & 6 & 7 \\
\hline
\end{tabular}

Panel A: Definition of isolated firms according to degree and betweenness

\begin{tabular}{l|c|c|c|c|c|c}
\hline Size & 109 & 7.91 & 1.46 & 304 & $8.08^{* *}$ & 1.41 \\
\hline Price-to-book value & 87 & 2.03 & 1.76 & 306 & $1.20^{* * *}$ & 0.97 \\
\hline Share of government owners & 150 & 0.00 & 0.00 & 462 & $9.95^{* * *}$ & 23.32 \\
\hline International experience & 167 & 0.19 & 0.20 & 466 & $0.24^{* * *}$ & 0.22 \\
\hline Government experience & 167 & 0.13 & 0.13 & 466 & $0.22^{* * *}$ & 0.16 \\
\hline
\end{tabular}

Panel B: Definition of isolated firms according to closeness

\begin{tabular}{l|c|c|c|c|c|c}
\hline Size & 103 & 7.82 & 1.16 & 322 & $8.14^{* * *}$ & 1.48 \\
\hline Price-to-book value & 105 & 1.07 & 0.95 & 318 & $1.37^{* * *}$ & 1.16 \\
\hline Share of government owners & 118 & 5.58 & 14.66 & 485 & $9.79^{* * *}$ & 23.92 \\
\hline International experience & 127 & 0.22 & 0.22 & 490 & $0.24^{* * *}$ & 0.22 \\
\hline Government experience & 127 & 0.22 & 0.16 & 490 & $0.20^{* * *}$ & 0.17 \\
\hline
\end{tabular}

Panel C: Definition of isolated firms according to eigenvector

\begin{tabular}{l|c|c|c|c|c|c}
\hline Size & 116 & 8.06 & 1.40 & 313 & 8.06 & 1.43 \\
\hline Price-to-book value & 100 & 1.52 & 1.23 & 293 & $1.24^{* * *}$ & 1.09 \\
\hline Share of government owners & 140 & 2.80 & 11.50 & 472 & $10.35^{* * *}$ & 23.93 \\
\hline International experience & 148 & 0.27 & 0.21 & 485 & $0.23^{* * *}$ & 0.22 \\
\hline Government experience & 148 & 0.16 & 0.16 & 485 & $0.22^{* * *}$ & 0.16 \\
\hline
\end{tabular}

Note: $* * *, * * *$ indicate significance at the 10,5 and $1 \%$ level, respectively.

Tests of mean comparisons between financial and non-financial firms

Table 8

\begin{tabular}{l|c|c|c|c|c|c}
\hline \multirow{2}{*}{ Network metrics } & \multicolumn{3}{|c|}{ Financial firms } & \multicolumn{3}{c}{ Non-financial firms } \\
\cline { 2 - 7 } Degree & $\mathbf{n}$ & Mean & Std. Dev. & $\mathbf{n}$ & Mean & Std. Dev. \\
\hline Betweenness & 579 & 13.78 & 6.26 & 6138 & 14.23 & 10.11 \\
\hline Closeness & 579 & 1193.81 & 3586.71 & 6138 & $2041.21^{* * *}$ & 5835.78 \\
\hline Eigenvector & 579 & 0.04 & 0.05 & 6138 & $0.03^{* *}$ & 0.06 \\
\hline Number of the other boards & 52 & 1.26 & 2.05 & 3077 & $2.45^{* *}$ & 3.91 \\
\hline
\end{tabular}

Note: $*, * *, * * *$ indicate significance at the 10,5 and $1 \%$ level, respectively. 
Table 9

Tests of mean comparisons between independent and non-independent directors

\begin{tabular}{l|c|c|c|c|c|c}
\hline \multirow{2}{*}{ Network metrics } & \multicolumn{3}{c|}{ Independent directors } & \multicolumn{3}{c}{ Non-independent directors } \\
\cline { 2 - 7 } & $\mathbf{n}$ & Mean & Std. Dev. & $\mathbf{n}$ & Mean & Std. Dev. \\
\hline Degree & 1709 & 14.54 & 9.44 & 4132 & $13.79^{* * * *}$ & 9.86 \\
\hline Betweenness & 1709 & 1982.99 & 5450.73 & 4132 & 2061.30 & 6072.57 \\
\hline Closeness & 1709 & 0.0258 & 0.0529 & 4132 & $0.0350^{* * *}$ & 0.0643 \\
\hline Eigenvector & 1709 & 0.0019 & 0.0038 & 4132 & $0.0015^{* * * *}$ & 0.0037 \\
\hline Number of the other boards & 840 & 2.13 & 3.03 & 1928 & $2.45^{* *}$ & 3.96 \\
\hline
\end{tabular}

Note: $*, * *, * * *$ indicate significance at the 10,5 and $1 \%$ level, respectively.

As shown in both Panel $\mathrm{A}$ and $\mathrm{C}$, the most connected firms in terms of degree, betweenness and eigenvector are larger, have a lower price-to-book value, higher degree of government ownership and employ directors with less international experience but greater government experience. However, the closeness metric offers another result. Given the negative correlation between closeness and the other metrics, we consider that the most relevant results are those in Panels A and C. They are consistent with the Russian corporate system, and with some large and well-connected firms in which the State plays an active role (both in terms of ownership and presence on the BoD), which does not necessarily translate to improved performance.

\subsection{Characteristics of the most isolated firms}

We then studied the characteristics of the most isolated firms. Again, we first defined isolated firms according to network metrics distributions. We took into account the lowest 25 percent of distribution for each variable. Degree and betweenness were analysed together for the above-mentioned reason. The results of t-tests are presented in Table 7 .

As expected, results in Panels $\mathrm{A}$ and $\mathrm{C}$ show that firms with fewer connections are smaller, have a high market valuation, and lower gov- ernment ownership, added to which their directors have less international and government experience. Once again, closeness centrality differs from the other metrics.

\subsection{Networks of financial institutions}

The next stage of the research analysed financial firms: banks, insurance firms and other financial institutions. The underlying assumption was that such firms should have better connections because they serve as mediators. We compared the means not only for network metrics but also for the number of outside directorships. The results of t-tests are presented in Table 8.

Contrary to our expectations, the results show that financial firms enjoy lower centrality in terms of betweenness and eigenvector. This means that directors of financial companies are not usually important mediators in the network, both in absolute terms and relative to their neighbours. The number of other directorships for directors of such firms is also significantly smaller. This result can be explained by reference to certain features of Russian companies: the choice of financial institution is rarely the director's decision and is instead determined by other factors such as the owner's decision and relationships. That is why it is not so important for these firms to hire particularly central directors. 
Tests of mean comparisons between political and non-political directors

\begin{tabular}{l|c|c|c|c|c|c}
\hline \multirow{2}{*}{ Network metrics } & \multicolumn{3}{c|}{ Political directors } & \multicolumn{3}{c}{ Non-political directors } \\
\cline { 2 - 7 } & $\mathbf{n}$ & Mean & Std. Dev. & $\mathbf{n}$ & Mean & Std. Dev. \\
\hline Degree & 1471 & 17.50 & 12.47 & 5010 & $13.34^{* * *}$ & 8.89 \\
\hline Betweenness & 1471 & 3192.11 & 6473.53 & 5010 & $1697.96^{* * * *}$ & 5504.22 \\
\hline Closeness & 1471 & 0.0182 & 0.0470 & 5010 & $0.0357^{\text {**** }}$ & 0.0632 \\
\hline Eigenvector & 1471 & 0.0027 & 0.0050 & 5010 & $0.0013^{* * * *}$ & 0.0030 \\
\hline Number of other boards & 647 & 2.32 & 3.00 & 2468 & 2.47 & 3.86 \\
\hline
\end{tabular}

Note: $*, * *, * * *$ indicate significance at the 10,5 and $1 \%$ level, respectively.

Table 11

Tests of mean comparisons between state-owned and private firms

\begin{tabular}{l|c|c|c|c|c|c}
\hline \multirow{2}{*}{ Network metrics } & \multicolumn{3}{c|}{ State-owned firms } & \multicolumn{3}{c}{ Private firms } \\
\cline { 2 - 7 } & $\mathbf{n}$ & Mean & Std. Dev. & n & Mean & Std. Dev. \\
\hline Degree & 5133 & 15.52 & 10.51 & 1582 & $9.90^{* * * *}$ & 5.32 \\
\hline Betweenness & 5133 & 2371.81 & 6277.39 & 1582 & $660.97^{* * *}$ & 2642.78 \\
\hline Closeness & 5133 & 0.0234 & 0.0508 & 1582 & $0.0591^{* * *}$ & 0.0770 \\
\hline Eigenvector & 5133 & 0.0021 & 0.0040 & 1582 & $0.0002^{* * *}$ & 0.0008 \\
\hline Number of other boards & 2299 & 4.39 & 4.33 & 819 & $3.85^{* * * *}$ & 3.56 \\
\hline
\end{tabular}

Not e: $* * *, * * *$ indicate significance at the 10,5 and $1 \%$ level, respectively.

Table 12

Tests of mean comparisons between oligarch-owned and non-oligarch-owned firms

\begin{tabular}{l|c|c|c|c|c|c}
\hline \multirow{2}{*}{ Network metrics } & \multicolumn{3}{c|}{ Oligarch-owned firms } & \multicolumn{3}{c}{ Non-oligarch-owned firms } \\
\cline { 2 - 7 } & $\mathbf{n}$ & Mean & Std. Dev. & $\mathbf{n}$ & Mean & Std. Dev. \\
\hline Degree & 1817 & 13.84 & 9.12 & 4719 & $14.58^{* * * *}$ & 10.17 \\
\hline Betweenness & 1817 & 1609.93 & 5128.79 & 4719 & $2172.22^{* * *}$ & 5963.03 \\
\hline Closeness & 1817 & 0.0306 & 0.0624 & 4719 & 0.0296 & 0.0570 \\
\hline Eigenvector & 1817 & 0.0013 & 0.0030 & 4719 & $0.0018^{* * * *}$ & 0.0039 \\
\hline Number of other boards & 894 & 3.67 & 3.52 & 2198 & $4.50^{* * *}$ & 4.37 \\
\hline
\end{tabular}

N ot e: $*, * *, * * *$ indicate significance at the 10,5 and $1 \%$ level, respectively.

\subsection{Centrality of independent directors}

At this stage of the research, we analysed how central the independent directors are. These directors are supposed to bring experience and resources to the board, and so should be more central and have better connections. The results of the relevant t-tests are presented in Table 9.

PЖM 18 (1): 29-50 (2020)
In line with our expectations, independent directors have more direct connections (higher degree) and higher relative importance (higher eigenvector) within their networks. They are characterized by lower closeness, which could indicate that these directors offer valuable connections but do not necessarily represent the shortest distance between different directors. Despite the results regarding centrality, we can see that, 
in general, independent directors sit on fewer other boards.

\subsection{Centrality of directors with political connections}

Since political connections are very important in Russian business, Russian companies, especially large ones, are likely to hire directors with political backgrounds. These directors enhance the firm's bargaining power and both simplify and accelerate the solving of important issues. This is one reason why they are included in several boards. Thus, the centrality of political directors should be higher than that of the rest of the network. The results of the relevant $t$ tests are presented in Table 10.

As expected, politically connected directors enjoy greater centrality. They have more direct connections than their non-political counterparts, they join sub-networks more often and have connections with more connected directors. However, despite high results for the other centrality metrics, we observed a lower value of closeness for political directors. Thus, the shortest average distance between these and other directors in the sample is higher. Again, the average number of other boards on which political directors serve is not statistically different to that for non-political directors.

\subsection{Centrality of directors in state- owned and oligarch-owned firms}

One particular feature of the Russian economic system is the high level of state involvement in the corporate system, particularly in companies that produce strategically important goods like gas, oil, metal, and chemical products. Thus, we analysed the centrality of directors in state-owned companies. Working in s state-owned company provides a unique experience that may enhance a director's appeal for other companies. As a result, we expect such directors to be more central. The main indicators of centrality and the $t$ - tests for means comparisons are presented in Table 11.

Consistent with these expectations, directors in state-owned companies have more direct connections (higher degree) with other directors, more direct connections (higher betweenness), and more relative importance (higher eigenvector) within their networks. They are also busier since, on average, they belong to 4.39 boards, while their colleagues from non-state companies sit on 3.85 other boards.

Another specific feature of the Russian economy is concentrated ownership and the emergence of controlling owners (so-called oligarchs) even in large quoted firms [Dolgopyatova, 2003; Lazareva, Rachinsky, Stepanov, 2008]. Guriev and Rachinsky define oligarchs as businessmen who control resources sufficient enough to influence national politics [Guriev, Rachinsky, 2005]. We draw on this definition and have checked the Forbes annual list of Russia's 25 richest businessmen. A person should own at least $\$ 4.5$ bn in order to be included in the list. Thus, we assume that the people in this list are oligarchs. Accordingly, we analysed the firms in which any oligarch owns any stake ${ }^{3}$. Our data confirms the economic importance of these people since approximately one-third of the firms in the sample are owned by oligarchs (Table 12). One might expect two contrasting profiles of directors in oligarch-owned firms. On the one hand, the special experience and success stories of these firms could attract well-connected directors. On the other hand, the power of the oligarch could eclipse the influence of the board of directors to such an extent that highly connected directors are not so necessary.

The results of the $t$-tests show that directors in oligarch-owned companies are less central in terms of degree, betweenness, and eigenvector metrics. They also hold fewer outside directorships. It seems that the board of directors does not play such a prom-

3 Mean oligarch ownership is $54.5 \%$, with three firms in the sample being totally owned by oligarchs. 
inent role in these firms, which might be due to the influence of the main shareholder who, by him/herself may be powerful enough to bring knowledge and other valuable resources to the firm.

\section{CONCLUSION}

This study uses the social network analysis to investigate a number of issues related to the BoDs of large Russian companies. One important characteristic of the Russian corporate system is the relevance of personal relationships for business. Consequently, we use social network analysis to verify the consistency of this trend.

Our study examined a sample of 107 listed Russian companies between 2009 and 2014 . Given the relative underdevelopment of Russian capital markets, our sample included only the most actively traded large firms. Since the unit of observation is a director and each firm employs up to 22 directors, we have 6729 director-year observations. Our data corroborates one feature of the Russian economic system; namely the concentration and importance of personal connections among directors as, compared to other countries, Russian directors have more outside directorships. Nevertheless, our preliminary analysis confirms improvement in BoDs: independence and international experience have increased, while the percentage of politically connected directors has fallen. Together with these initial issues, social network analysis draws a complementary picture.

We chose four quite popular network analysis metrics which have already been implemented for board analysis elsewhere: degree centrality, betweenness centrality, closeness centrality, and eigenvector centrality. Since each of these metrics provides information about different network characteristics, they are analysed together. Thus, degree is regarded as a metric of popularity, betweenness is the ability to join sub-networks, closeness is the average shortest distance from one director to others, and eigenvector pro- vides information on how connected the nodes of the network are to a particular director.

First, we studied the evolution of these network metrics. The most consistent result was the decrease in centrality from 2009 to 2014 (both in terms of degree and eigenvector centrality). Since the average size of the boards did not change much, these results confirm a trend away from power concentration in the hands of just a few directors. Second, we analysed the characteristics of the most connected and the most isolated boards according to network metrics, and we made some mean comparisons with the rest of the sample. Our results show that the most connected firms are larger, have lower market valuations, and stronger ties with government (both through higher fractions of government owned shares and greater numbers of directors who are former politicians). Third, we made some mean comparisons for several specific cases: the connections of the boards of financial institutions, the connections of directors with a political background, and the connections of independent directors. Contrary to our expectations, the boards of financial institutions are less central. Both independent and directors with political connections play a more central role, which suggests that these directors are hired to bring in valuable resources and connections.

Two additional features of the Russian economic system are State involvement as a shareholder of some firms, and the prominent role played by certain influential shareholders (so-called oligarchs). We found that state-owned firms have a more central position in the economy, with their directors being better connected and having more outside directorships. Interestingly, our results suggest that in the firms owned by oligarchs the board of directors does not seem to play such a relevant role, in the sense that their directors are less centralized and are less frequently appointed to other firms.

Our findings are useful for academia, policy makers, and practitioners alike. As for

PЖM 18 (1): 29-50 (2020) 
the research, the paper sheds light on how Russian companies transfer knowledge and resources. Moreover, our research can motivate similar inquiries in other emerging countries in which business networks play a relevant role. Also, from a theoretical point of view, our results can be used as a foundation for further empirical evaluation of corporate centrality outcomes in an intersection of the agency theory and resource dependence view. As for policy makers, we provide complementary evidence to traditional corporate governance indicators. Given the international concern for improving corporate governance, legal authorities can find in our research new approaches for testing the efficiency of rules aimed at strengthening national corporate governance. Although Russia has some specific characteristics, the study of the Russian case can be interesting for authorities in other countries, especially in those with less developed markets and for emerging economies. Personal connections arise as a way to overcome the failures of not very developed markets. Thus, the evidence of the Russian economic system can help authorities in other emerging countries to implement political measures to exploit the positive side of these connections and avoid the negative implications of these informal mechanisms.

As for practitioners, our research offers managers, directors and investors valuable guides. Decision makers in firms, such as managers and directors, may take advantage of our findings when deciding the profile of directors who are being considered to join the board, in terms of ensuring the transfer of knowledge and other resources. In this vein, firms can exploit the potential benefits pro- vided by the most central directors. In addition, investors (mainly institutional investors) can benefit from our approach by identifying directors as a source of value for firms and making more precise valuations of a firm's stocks.

Our paper marks a step forward in the use of the social network approach to study corporate governance and points the way for various lines of future research. An interesting subject of analysis would be the networks of the directors of financial institutions. Since Russian boards in such institutions are not as central as expected, further research should seek to shed light on the role of bankers in the corporate governance system and its relationship to how firms raise funds. Related to this, another possible direction for further investigation could be the impact of director networks on other firm-level issues such as firm profitability, the quality of financial information and corporate finance, or other strategic decisions. Whatever the case, social network analysis shows itself to be a powerful tool to complement classical corporate governance analyses.

\section{ACKNOWLEDGEMENTS}

The authors are grateful to an anonymous referee, P. Jaggs, E. Shakina, M. Molodchik, P. Parshakov, I. Naidenova, S. Vedernikov, V. Kuskova, and participants at the Networks in the Global World 2016 conference held in Saint Petersburg and the XVIII April International Academic Conference on Economic and Social Development held in Moscow. Any remaining errors are the authors' sole responsibility.

Appendix 1

\section{DEFENITIONS OF TERMS}

\begin{tabular}{c|l|c}
\hline Term & \multicolumn{1}{|c|}{ Definition } & \multicolumn{1}{c}{ Measurement in the paper } \\
\hline $\mathbf{1}$ & \multicolumn{1}{c}{$\mathbf{2}$} & $\mathbf{3}$ \\
\hline Network & $\begin{array}{l}\text { Representation of a system in which } \\
\text { the elements are connected by ties } \\
\text { [Wasserman, Galaskiewicz, 1994] }\end{array}$ & Directors that are connected by ties \\
\hline
\end{tabular}


Appendix 1 (continued)

\begin{tabular}{|c|c|c|}
\hline Term & Definition & Measurement in the paper \\
\hline $\mathbf{1}$ & 2 & 3 \\
\hline Node & The element of network & One director \\
\hline Tie & $\begin{array}{l}\text { Direct connection between nodes of } \\
\text { a network that are used for sharing } \\
\text { information, knowledge, feelings, and } \\
\text { experiences }\end{array}$ & Connections via formal contacts (board meetings) \\
\hline Path & $\begin{array}{l}\text { The direct or indirect connection } \\
\text { between two nodes. The aggregate of } \\
\text { ties that information passes through to } \\
\text { get from element A to element B }\end{array}$ & $\begin{array}{l}\text { The aggregate of ties between directors that infor- } \\
\text { mation passes through to get from director A to } \\
\text { director B }\end{array}$ \\
\hline Centrality & The importance of a node in a network & $\begin{array}{l}\text { The importance of one director among the others } \\
\text { in a network }\end{array}$ \\
\hline $\begin{array}{l}\text { Degree } \\
\text { centrality }\end{array}$ & The number of ties a given node has & $\begin{array}{l}\text { The number of directors a director is in direct con- } \\
\text { tact with by sitting on the same board } \\
\qquad \text { Degree }_{i}=\frac{\sum_{j} X_{i j}}{g-1} \text {, } \\
\text { where } i \text { is a particular director, } j-\text { all directors } \\
\text { other than } i \text {; } X_{j i} \text { takes the value } 1 \text { if director } i \text { and } \\
\text { director } j \text { are on the same board, and } 0 \text { otherwise; } \\
g \text { is the number of directors in the board network }\end{array}$ \\
\hline $\begin{array}{l}\text { Betweenness } \\
\text { centrality }\end{array}$ & $\begin{array}{l}\text { The degree to which the same node } \\
\text { reduces the path distance between all } \\
\text { pairs of other nodes [Chen, Wang, Lin, } \\
2015 \text { ] }\end{array}$ & $\begin{array}{l}\text { The number of times a given director acts as a tie } \\
\text { to form the shortest path between all pairs of oth- } \\
\text { er directors } \\
\text { Betweenness }{ }_{i}=\frac{\sum_{j<k} g_{j k(n i)} / g_{j k}}{(g-1)(g-2)} \text {, } \\
\text { where } g_{j k(n i)} \text { is the number of geodesics in which } \\
\text { director } j \text { communicates with director } k \text { through } \\
\text { director } i \text {; } g_{j k} \text { is the number of geodesics in which } \\
\text { director } j \text { communicates with director } k \text {; } g \text { is the } \\
\text { number of directors in the board network. The prod- } \\
\text { uct }(g-1)(g-2) \text { is used to eliminate the differ- } \\
\text { ences in board size }\end{array}$ \\
\hline $\begin{array}{l}\text { Closeness } \\
\text { centrality }\end{array}$ & $\begin{array}{l}\text { The average length of the shortest path } \\
\text { between a node and all the other nodes } \\
\text { in the network [Chen, Wang, Lin, } \\
2015 \text { ] }\end{array}$ & $\begin{array}{l}\text { The average length of the shortest path between } \\
\text { a director and all the other directors of the boards } \\
\text { Closeness }_{i}=\left(\frac{\sum_{j=1}^{g} d(i, j)}{g-1}\right)^{-1}, \\
\begin{array}{l}\text { where } d(i, j) \text { is the distance between director } i \text { and } \\
\text { director } j ; g \text { is the number of directors in the board } \\
\text { network }\end{array}\end{array}$ \\
\hline
\end{tabular}


Appendix 1 (end)

\begin{tabular}{c|l|l}
\hline \multicolumn{1}{c|}{ Term } & \multicolumn{1}{|c}{ Definition } & \multicolumn{1}{c}{ Measurement in the paper } \\
\hline $\mathbf{1}$ & \multicolumn{1}{|c}{$\mathbf{2}$} & \multicolumn{1}{c}{$\mathbf{c}$} \\
\hline $\begin{array}{l}\text { Eigenvector } \\
\text { centrality }\end{array}$ & $\begin{array}{l}\text { The extent to which a node's network } \\
\text { centrality is related to that of its } \\
\text { neighbours [Bonacich, 1972] }\end{array}$ & $\begin{array}{l}\text { The extent to which a director's centrality is } \\
\text { related to the centrality of directors connected to } \\
\text { him/her by ties }\end{array}$ \\
$\begin{array}{c}\text { Eigenvector } i=\frac{1}{\lambda} \sum_{j} b_{i j} E_{j}, \\
\text { where } b_{i j} \text { is an adjacency matrix that takes the val- } \\
\text { ue of } 1 \text { if director } i \text { and director } j \text { are on the same } \\
\text { board, and } 0 \text { otherwise; } \lambda \text { is the largest eigenvalue; } \\
E_{j} \text { is the eigenvalue of director } j \text { 's centrality }\end{array}$ \\
\hline
\end{tabular}

Appendix 2

\section{CORRELATION MATRIX FOR CENTRALITY METRICS}

\begin{tabular}{l|c|c|c}
\hline & Degree & Betweenness & Closeness \\
\hline Betweenness & $0.7277 * * *$ & & \\
\hline Closeness & $-0.3524 * * *$ & $-0.1812 * * *$ & $-0.2321 * * *$ \\
\hline Eigenvector & $0.6389 * * *$ & $0.3538 * * *$ & \\
\hline
\end{tabular}

Note: $* * *, * * *$ indicates significance at the $1 \%$ level.

\section{REFERENCES}

Adams R. B., Hermalin B.E., Weisbach M.S. 2010. The role of boards of directors in corporate governance: A conceptual framework and survey. Journal of Economic Literature 48 (1): 58-107.

Andres C., van den Bongard I., Lehmann M. 2013. Is busy really busy? Board governance revisited. Journal of Business Finance \& Accounting 40 (9-10): 1221-1246.

Barnea A., Guedj I. 2007. Sympathetic boards: director networks and firm governance. $\mathrm{Eu}$ ropean Finance Association Conference. Ljubljana.

Blanco-Alcántara D., Díez-Esteban J.M., Romero-Merino M.E. 2019. Board networks as a source of intellectual capital for companies: Empirical evidence from a panel of Spanish firms. Management Decision $\mathbf{5 7}$ (10): 2653-2671.
Böhler D., Rapp M. S., Wolff M. 2010. Director Networks, Firm Performance, and Shareholder Base. Available at: http://ssrn.com/ abstract=1691241 (accessed: 20.03.2020).

Bohman L. 2012. Bringing the owners back in: An analysis of a 3-mode interlock network. Social Networks 34 (2): 275-287.

Bonacich P. 1972. Factoring and Weighting Approaches to Status Scores and Clique Identification. Journal of Mathematical Sociology 2: 113-120.

Cárdenas J.-C. 2015. Are Latin America's corporate elites transnationally interconnected? A network analysis of interlocking directorates. Global Networks 15 (4): 424-445.

Comet C., Pizarro N. 2011. The cohesion of intercorporate networks in France. ProcediaSocial and Behavioral Sciences 10: 52-61.

Core J.E., Holthausen R.W., Larcker D.F. 1999. Corporate governance, chief executive officer compensation, and firm perfor-

PЖM 18 (1): 29-50 (2020) 
mance. Journal of Financial Economics 51 (3): 371-406.

Chan A. L.-C., Lee E., Petaibanlue J., Tan N. 2017. Do board interlocks motivate voluntary disclosure? Evidence from Taiwan. Review of Quantitative Finance and Accounting 48: 441-466.

Chen G., Wang X., Li X. 2015. Fundamentals of Complex Networks: Models, Structures and Dynamics. Wiley.

Chen H.-L., Hsu W.-T., Chang C.-Y. 2016. Independent directors' human and social capital, firm internationalization and performance implications: An integrated agencyresource dependence view. International Business Review 25 (4): 859-871.

Chuluun T., Prevost A., Puthenpurackal J. 2014. Board ties and the cost of corporate debt. Financial Management 43 (3): 533568.

De B. 2012. Incidence and Performance Effects of Interlocking Directorates in Emerging Market Business Groups: Evidence from India. Working paper. IGIDR.

Devos E., Prevost A., Puthenpurackal J. 2009. Are interlocked directors effective monitors? Financial Management 48: 861-887.

Dolgopyatova T. 2003. Ownership and corporate control structures as viewed by statistics and surveys. Russian Economic $\mathrm{Ba}$ rometer 12 (3): 12-20.

Durbach I. N., Parker H. 2009. An analysis of corporate board networks in South Africa. South African Journal of Business Management 40 (2): 15-26.

Enikolopov R., Stepanov S. 2013. Corporate governance in Russia. In: Alexeev M., Weber S. (eds). The Oxford Handbook of the Russian Economy. Oxford University Press: N.Y.

Fich E. M., Shivdasani A. 2006. Are busy boards effective monitors? Journal of $\mathrm{Fi}$ nance 61 (2): 689-724.

Fich E.M., White L.J. 2005. Why do CEOs reciprocally sit on each other's boards? Journal of Corporate Finance 11 (1-2): 175-195.

Freeman L. C. 1978. Centrality in social networks: Conceptual clarification. Social Networks 1 (3): 215-239.
Frye T. M., Iwasaki I. 2011. Government directors and business-state relations in Russia. European Journal of Political Economy 27 (4): 642-658.

Goriaev A., Zabotkin A. 2006. Risks of investing in the Russian stock market: Lessons of the first decade. Emerging Markets Review 7 (4): 380-397.

Granovetter M.S. 1973. The strength of weak ties. American Journal of Sociology 78 (6): 1360-1380.

Guriev S., Rachinsky A. 2005. The role of oligarchs in Russian capitalism. Journal of Economic Perspectives 19 (1): 131-150.

Hayden F. G., Garner A. D., Hoffman J. 2013. Corporate, social, and political networks of Koch Industries Inc. and TD Ameritrade Holding Corporation: Extension to the State of Nebraska. Journal of Economic Issues 47 (1): 63-94.

Horton J., Millo Y., Serafeim G. 2012. Resources or power? Implications of social networks on compensation and firm performance. Journal of Business Finance \& Accounting 39 (3-4): 399-426.

Iwasaki I. 2008. The determinants of board composition in a transforming economy: Evidence from Russia. Journal of Corporate Finance 14 (5): 532-549.

Iwasaki I. 2013. Firm-level determinants of board system choice: Evidence from Russia. Comparative Economic Studies 55 (4): 636-671.

Iwasaki I. 2014. Global financial crisis, corporate governance, and firm survival: The Russian experience. Journal of Comparative Economics 42 (1): 178-211.

Kawai N., Ko J.-H. 2012. The dark sides of institutionalized informal connections: Evidence from the Japanese banking sector in the post-bubble crisis era. International Journal of Business 17 (3): 238-257.

Kim Y. 2005. Board network characteristics and firm performance in Korea. Corporate Governance: An International Review $\mathbf{1 3}$ (6): 800-808.

Lai J.-H., Chen L.-Y., Song S. 2019. How outside directors' human and social capital create value for corporate international invest- 
ments. Journal of World Business 54 (2): 93-106.

Larcker D.F., So E.C., Wang C.C. Y. 2013. Boardroom centrality and firm performance. Journal of Accounting and Economics $\mathbf{5 5}$ (2): $225-250$.

Lazareva O., Rachinsky A., Stepanov S. 2008. A survey of corporate governance in Russia. In: McGee R.W. (ed.). Corporate Governance in Transition Economies. Springer: N.Y.

Li C., Li Q., Van Mieghem P., Stanley H.E., Wang H. 2015. Correlation between centrality metrics and their application to the opinion model. The European Physical Journal B 88 (3): 1-13.

Madhani P. M. 2017. Diverse roles of corporate board: Review of various corporate governance theories. The IUP Journal of Corporate Governance 16 (2): 7-28.

Mendes-Da-Silva W. 2011. Small worlds and board interlocking in Brazil: A longitudinal study of corporate networks, 1997-2007. Brazilian Finance Review 9 (4): 465-492.

Michailova S., Worm V. 2003. Personal networking in Russia and China: Blat and Guanxi. European Management Journal 21 (4): 509519.

Muravyev A. 2017. Boards of directors in Russian publicly traded companies in 19982014: Structure, dynamics and performance effects. Economic Systems 41 (1): 5-25.

Muravyev A., Berezinets I., Ilina Y. 2014. The structure of corporate boards and private benefits of control: Evidence from the Russian stock exchange. International Review of Financial Analysis 34: 247-261.

Pfeffer J., Salancik G.R. 2003. The external control of organizations: A Resource Dependence Perspective. Stanford University Press: Stanford.

Pombo C., Gutiérrez L.H. 2011. Outside directors, board interlocks and firm performance: Empirical evidence from Colombian business groups. Journal of Economics and Business 63 (4): 251-277.

Prokofieva M., Muniandy B. 2011. Board composition and audit fee: evidence from Russia. Corporate Ownership and Control 8 (2): $551-565$.
Purkayastha S., Manolova T.S., Edelman L.F. 2012. Diversification and performance in developed and emerging market contexts: A review of the literature. International Journal of Management Reviews 14 (1): 18-38.

Qiao P., Fung H.-G., Ju X. 2013. Effects of social capital, top executive attributes and $R \& D$ on firm value in Chinese small and medium-sized enterprises. China \& World Economy 21 (4): 79-100.

Santos R.L., Da Silveira A.D. M., Barros L.A. 2012. Board interlocking in Brazil: directors' participation in multiple companies and its effect on firm value and profitability. Latin American Business Review 13 (1): 1-28.

Schiehll E., Martins H.C. 2016. Cross-national governance research: A systematic review and assessment. Corporate Governance: An International Review 24 (3): 181-199.

Schonlau R., Singh P.V. 2009. Board Networks and Merger Performance. Working paper. Carnegie Mellon University.

Silva F., Majluf N., Paredes R.D. 2006. Family ties, interlocking directors and performance of business groups in emerging countries: The case of Chile. Journal of Business Research 59 (3): 315-321.

Singh D., Delios A. 2017. Corporate governance, board networks and growth in domestic and international markets: Evidence from India. Journal of World Business 52 (5): 615-627.

Sitthipongpanich T., Polsiri P. 2015. Do CEO and board characteristics matter? A study of Thai family firms. Journal of Family Business Strategy 6 (2): 119-129.

SpencerStuart. 2018. 2018 Russia Spencer Stuart Board Index.

Steckler E., Clark C. 2019. Authenticity and corporate governance. Journal of Business Ethics 155 (4): 951-963.

Valente T. W., Coronges K., Lakon C., Costenbader E. 2008. How correlated are network centrality measures? Connections 28 (1): 16-26.

Wasserman S., Galaskiewicz J. 1994. Advances in Social Network Analysis: Research in the Social and Behavioral Sciences. SAGE Publications. 
Withers M., Kim J.Y., Howard M. 2018. The evolution of the board interlock network following Sarbanes-Oxley. Social Networks 52: $56-67$.

Yigit I., Behram N.K. 2013. The relationship between diversification strategy and organizational performance in developed and emerging economy contexts: Evidence from Turkey and Netherlands. Eurasian Business Review 3 (2): 121-136.
Zona F., Boyd B. K., Takacs Haynes K. 2019. Coordination, control, or charade? The role of board interlocks among business group members. Management Decision 57 (10): 2630-2652.

Zona F., Gomez-Mejia L.R., Withers M.C. 2018. Board interlocks and firm performance: Toward a combined agency-resource dependence perspective. Journal of Management 44 (2): $589-618$.

Initial Submission: January 13, 2020

Final Version Accepted: March 24, 2020

Связи советов директоров российских колпаний: скрытая часть систель корпоративного управления

\section{М.А. Завертяева}

Международная лаборатория экономики нематериальных активов, Национальный исследовательский университет «Высшая школа экономики», Россия

\section{Ф. X. Лоnec-Hmyppuaza}

Школа бизнеса и экономики, Университет Вальядолида, Испания; Международная лаборатория экономики нематериальных активов, Национальный исследовательский университет «Высшая школа экономики», Россия

В статье рассматривается применение сетевого анализа для исследования советов директоров 107 крупных торгуемых на бирже российских компаний в период с 2009 по 2014 г. Традиционные показатели корпоративного управления, такие как демографические характеристики, опыт и вхождение директора в несколько советов, подтверждают рост их независимости и квалификации. Результаты исследования свидетельствуют о снижении концентрации власти в руках некоторых директоров. Фирмы с наиболее тесными связями характеризуются крупным размером, более низкой рыночной капитализацией и более сильными связями с правительством (благодаря увеличению как доли акций, принадлежащих государству, так и количества директоров, которые являются бывшими политиками). Кроме того, было обнаружено, что советы директоров финансовых учреждений менее взаимосвязаны, тогда как политические и независимые директора, как правило, занимают центральную позицию в сети.

Ключевые слова: совет директоров, корпоративное управление, российские компании, сетевой анализ.

JEL: G34, C45.

For citation: Zavertiaeva M.A., López-Iturriaga F.J. 2020. Networks of directors on Russian boards: The hidden part of the corporate governance iceberg. Russian Management Journal 18 (1): $29-50$.

Статья поступила в редакиию 13 января 2020 г. Принята к публикации 24 ларта 2020 г. 